Hancheva O. V., Romanova K. B. Vision of the role of long-term social stress in the formation of "diseases of civilization". mechanisms of adaptation to stressor situations and factors of its failure. Journal of Education, Health and Sport. 2021;11(10): 325331. eISSN 2391-8306. DOI http://dx.doi.org/10.12775/JEHS.2021.11.10.031

https://apcz.umk.pl/JEHS/article/view/JEHS.2021.11.10.031

https://zenodo.org/record/5733002

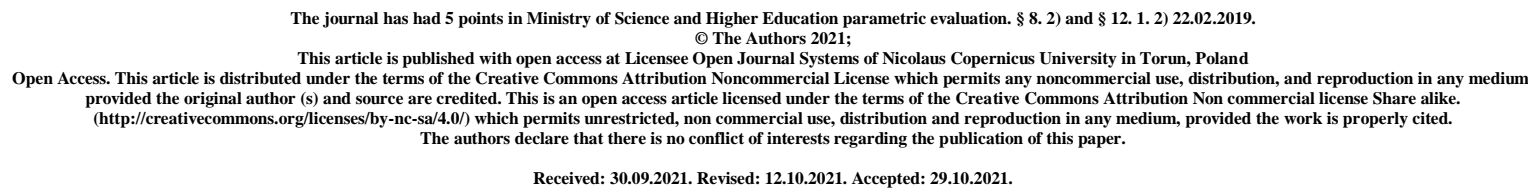

UDC: 616: 572.26]: 159.944.4]] - 044.332

\title{
VISION OF THE ROLE OF LONG-TERM SOCIAL STRESS IN THE FORMATION OF "DISEASES OF CIVILIZATION". MECHANISMS OF ADAPTATION TO STRESSOR SITUATIONS AND FACTORS OF ITS FAILURE
}

\author{
O. V. Hancheva, K. B. Romanova
}

Zaporizhzhia State Medical University

Department of Pathological Physiology with the Course of Normal Physiology

Hancheva O.V, MD, PhD, DSc, Professor, Head of the Department of Pathological Physiology with the Course of Normal Physiology, Zaporizhzhia State Medical University, Ukraine.

ORCID iD: 0000-0001-7339-7078; Web of Science ResearcherID: X-9959-2019

Romanova K.B., MD, Assistant of the Department of Pathological Physiology with the course of normal physiology, Zaporizhzhia State Medical University, Zaporizhzhia, Ukraine.

zsmusimul@gmail.com;+380666246792

\section{Abstract}

Today, the issue of studying the mechanisms of the impact of social stress on public health and its role in the formation of key human diseases is relevant and necessary. A large number of works, both clinical observations and experimental studies, are devoted to this problem. However, despite the high interest in this problem, there are still "white spots". Therefore, the purpose of our study was to analyze modern sources of information that highlight current issues of long-term social stress and its role in the formation of "diseases of civilization." Matherials and methods: analysis of scientific publications from the following databases: Google Scholar, Web of Science, Pub Med, by keywords: rats, social stress, 
diseases of civilization, neuroendocrine regulation, hypothalamus, supraoptic nucleus, paravetricular nucleus. Conclusions: Thus, the analysis of resources shows the undoubted role of stress in the formation of human diseases. Many articles are devoted to the description and analysis of the negative effects of environmental factors and peculiarities of living conditions on human health. Most researchers agree on the key role of the hypothalamus in regulating the body's stress response and the presence of morphofunctional changes associated with stress. It is important to note that scientists have paid much attention to the study of individual models of stress, namely pain, immobilization and hypoxic over the past 20 years. Unfortunately, there are few facts concerning the analysis of the influence of longterm negative social factors that do not cause stereotyped reactions, but form latent changes that are inherent in classical stress reactions.

Key words: rats; social stress; diseases of civilization; neuroendocrine regulation; hypothalamus; supraoptic nucleus; paravetricular nucleus.

Introduction: The last decade has been characterized by a steady increase in the amount of mental and physical health disorders in the structure of human diseases. According to the WHO, the main factors in their formation are various kinds of excessive stress and negative social factors [1].

Today, there is no doubt that a contemporary man is less exposed to natural biological stressors, which require immediate action, but more and more often he is followed by the daily loads of civilization's negative factors. The difficulty of an adequate response to them is the disability to respond with the usual natural means, namely a fight or escape from conflict. However, the stress of modern life, which is psychosocial in nature, is realized through welldefined biological mechanisms that affect the unchanging biological essence of man and his physiological health [2].

As early as the beginning of the twentieth century, the opinions of famous scientists that civilization makes a person a "neurotic" are becoming even more relevant today, due to the emergence of new high-tech factors. High urbanization in large cities and long-term congestion of people with limited living space are becoming invisible slow factors in the development of diseases. There are assumptions, which are already partially confirmed by clinical observations and experimental studies that such social factors as working and living conditions, social status, financial security and others must be taken into account in the formation of "diseases of civilization" among the etiological factors [3].

It is proved that in the beginning as a result of influence of these negative factors the 
general adaptation syndrome or resistance of an organism to stress is formed [4]. However, as the adaptive capacity is exhausted, the body's regulatory systems fail disadaptation and irreversible pathological changes. Many recent studies clearly demonstrate the connection between stress and the development of various somatic diseases (gastrointestinal ulcers, hypertension, cardiovascular disease, tumors, diabetes, etc.) [5-7].

At the same time, the mechanisms that explain the occurrence of pathological conditions under the influence of stressors of various natures have not been fully studied. According to the traditional understanding, the reaction to a stress response happens due to the participation of many regulatory systems - the CNS, autonomic nervous system (ANS) and the system of neuroendocrine regulation. Within the latter mechanism, a special role belongs to the hypothalamic-pituitary-corticoid axis, especially when it concerns the longterm negative signals of the social environment [8].

Today, the issue of studying the mechanisms of the impact of social stress on public health and its role in the formation of key human diseases is relevant and necessary. A large number of works, both clinical observations and experimental studies, are devoted to this problem. However, despite the high interest in this problem, there are still "white spots". Therefore, the purpose of our study was to analyze modern sources of information that highlight current issues of long-term social stress and its role in the formation of "diseases of civilization."

Matherials and methods: analysis of scientific publications taken from databases Google Scholar, Web of Science, Pub Med by keywords: rats, social stress, diseases of civilization, neuroendocrine regulation, hypothalamus, supraoptic nucleus, paravetricular nucleus.

Modern visions of the mechanisms of adaptation to stressful situations and stresslimiting systems of the body

Situations in which the environment sets the body a new task, form a general adaptive stress response. This reaction not only precedes the development of sustainable adaptation, but plays an important role in its formation. Its development is ensured, firstly, by mobilizing the energy and structural resources of the body, and secondly, the direction of their redistribution towards the predominant provision of the systems responsible for adaptation to this factor. In these systems, a systemic structural trace is formed by the direct influence of stress hormones and mediators on the metabolism and function of system cells [4].

As the systemic structural trace and stable adaptation is formed with a change in homeostasis, both the stress response itself, which played its role in the formation of 
adaptation, gradually disappears, and the imbalance of homeostasis is gradually eliminated. This determines the relationship between stress and adaptation and emphasizes that the stress response has evolved as a necessary, nonspecific link in a more complex holistic mechanism of adaptation. However, this value of stress response in the life of the organism is not limited. In real life, there are so-called deadlocks, when the requirements of the environment can not be realized through specific behavioral or other reactions, while the formation of an adequate response and systemic structural trace is impossible, so adaptation is not realized [8].

Under the action of an extremely strong unconditional stimulus - a significant load, cold, hunger, pain, which one can not get rid of from, these situations are assessed as situations of "forced patience". Under the influence of stereotypical conditioned stimuli, which act as signals of approaching damaging factors, as well as with the long-term maintenance of the gap between strong need and lack of information on whether it can be met, these situations are assessed as "traps" and "anxiety". In all situations of this kind, the lack of ability to adapt leads to the fact that the disturbances of homeostasis, which are a stimulus to stress, persist for a long time. Long-term violation of the adrenergic and pituitary-adrenal systems, which form a stress response [8].

As a result of unusually long and intense action of high concentrations of catecholamines and glucocorticoids, various injuries occur, which are a group of so-called stress diseases, which occupy one of the main places in the modern medicine. At present, the role of stress as the main or auxiliary etiological factor of gastric ulcer, hypertension, atherosclerosis, disorders of the function and structure of the heart, immunodeficiency and even malignant tumors has been proven [5-7]. These facts mean that under certain circumstances, the stress syndrome from the general non-specific component of the body's adaptation to various environmental factors becomes a non-specific element in the pathogenesis of diseases that limit the duration of human life.

The role of stress in pathology is so popular that it often obscures its basic evolutionarily determined significance as the component of adaptation, and prevents us from focusing on the most important circumstances, that most people and animals who are put in so-called deadlocks do not die, but acquire some degree of resistance to these stressful situations. Such stressful situations in the form of long periods of cold, natural disasters, interspecific and intraspecific conflicts, limitation of living space, are always widely represented in the natural habitat in which animals successfully adapt [9].

Unfortunately, in the habitat of Homo sapiens qualitatively more complex socially determined stressful situations are as much widely represented. Indeed, only during the last 
period of its history the humanity has passed through periods of slavery, serfdom, world wars and at the same time not degraded, thus demonstrating the high efficiency of adaptation to the so-called hopeless stressful situations. This means that the temporary transformation of the stress response from the element of adaptation to the element of pathogenesis is not the end of the life process, but its intermediate stage. The process is not limited to this transformation most animals and humans do not die from long-term and repeated stressful situations, but they form chronic diseases that worsen the quality of life and reduce its duration [8].

Adaptation to stressful situations can be described as a process that ensures the preservation of life, active work of the body and prevents its disease in dangerous situations that are potentially damaging, but which can not be overcome by simple avoidance and rescue reactions by specific adaptation to any physical, chemical or biological stress factor [10].

Externally, such adaptation is expressed by two well-reproduced phenomena. Firstly, the transformation of behavior, as a result of which the specialized work of people or complex behavioral skills of animals allow them to adapt to complex conditions. Secondly, the fact that emotionally painful stressful situations, which previously naturally caused damage to certain systems and organs, after the development of adaptation lose the ability to cause such damage. Thus, researchers have revealed that standard emotional pain and immobilization stressors in maladapted animals led to ulcerative lesions of the gastric mucosa, myocardial damage and impaired contractile function, also contributed to a sharp decrease in the activity of an important part of antitumor immunity - natural killers. These stressors lose their damaging properties after adaptation due to the relatively few short, deliberately nondamaging stressors that can be considered as training factors [10]. Since successful activities in extreme natural and social conditions, as well as prevention in these conditions of major noncommunicable diseases are important tasks of the modern stage of civilization, it is obvious that the study of adaptation to stressful situations and management is one of the main tasks of modern pathophysiology and experimental medicine.

\section{Damaging stressful situation and adaptation to it}

Various situations that cause severe and long-term stress, dangerous because of damage to internal organs, ultimately come down to the conflict between the imperative need to immediately carry out defensive, food, sexual reactions and an irresistible prohibition on these reactions. In a more complex form, this conflict is realized when a person experiences socially determined influences that threaten his existence or dignity, and the prohibition of such a reaction is imposed by other (also socially determined) conditions that require endurance to avoid even greater dangers [10]. 
This endurance is provided by critical stress of the mechanisms of inhibition of cortical brain activity, but only the external behavioral component of the reaction becomes inhibited or altered. Its internal autonomic component, ie the stress syndrome, which is realized through the mobilization of circulatory, respiratory functions, etc., is preserved and may even be more intense and prolonged than in the implementation of the behavioral response itself. This situation is characterized by the fact that the increased stress syndrome is manifested by prolonged and significant increases in the concentration of catecholamines and glucocorticoids in the blood [11-13].

Conclusions: Thus, the analysis of resources shows the undoubted role of stress in the formation of human diseases. Many articles are devoted to the description and analysis of the negative effects of environmental factors and peculiarities of living conditions on human health. Most researchers agree on the key role of the hypothalamus in regulating the body's stress response and the presence of morphofunctional changes associated with stress. It is important to note that scientists have paid much attention to the study of individual models of stress, namely pain, immobilization and hypoxic models over the past 20 years. Unfortunately, there are few facts concerning the analysis of the influence of long-term negative social factors that do not cause stereotyped reactions, but form latent changes that are inherent in classical stress reactions.

\section{References:}

1. (2021). Retrieved 17 November 2021, from https://www.who.int/news-room/factsheets/detail/mental-health-and-forced-displacement

2. Osipova I.V., Antropova O.N. Stress-reaktivnost: klinicheskie aspektyi. Byulleten meditsinskoy nauki.2017. \# 1, T. 5. S. 61-64. Russian.

3. Aleksieva D.A. Vozmozhnosti kontrolya za stressom $\mathrm{v}$ organizatsii: opyit Evropeyskogo Soyuza. Nauchnyiy dialog. 2015, \#1, T. 37. S. 171-179. Russian.

4. Malyigina O.A. Problemyi meditsinskoy normyi i donozologicheskaya diagnostika. Meditsina: teoriya i praktika. 2020. T. 5, \# 4. S. 3-9. Russian.

5. E.V. Akimova, M.I. Bessonova, V.V. Gafarov. Assotsiatsii rasprostranennosti stressa na rabote $\mathrm{i}$ ishemicheskoy bolezni serdtsa $\mathrm{v}$ otkryitoy gorodskoy populyatsii. Kompleksnyie problemyi serdechno-sosudistyih zabolevaniy. 2018. T.7, \# 4. S. 70-76. Russian.

6. Solopova A., Idrisova L., Chukanova E., Alipova V. Neyroimmunologiya v onkologii: vozdeystvie stressa na bolezn. Vrach. 2017. \# 9. S. 14-16. Russian. 
7. Shulga P.M. Rol stressa $\mathrm{v}$ patogeneze bolezni Altsgeymera. Integrativnaya fiziologiya. 2020. T. 1, \# 3. S. 249-252. Russian.

8. Russell, G., \& Lightman, S. (2019). The human stress response. Nature reviews. Endocrinology, 15(9), 525-534. https://doi.org/10.1038/s41574-019-0228-0

9. Sokolova L.P. Adaptatsiya k stressu - osnovopolagayuschiy faktor zhiznesposobnosti i kognitivnoy aktivnosti. Klinicheskaya gerontologiya. 2011. T. 5, \# 6. S. 16-20. Russian.

10. Loseva E.V. Psihosotsialnyiy stress perenaselennosti (skuchennosti): negativnyie posledstviya dlya cheloveka i gryizunov. Integrativnaya fiziologiya. 2021. T. 2, \# 1. S. 33-40. Russian.

11. Pellissier, S., \& Bonaz, B. (2017). The Place of Stress and Emotions in the Irritable Bowel Syndrome. Vitamins and hormones, 103, 327-354. https://doi.org/10.1016/bs.vh.2016.09.005.

12. Muscatello, M. R., Bruno, A., Scimeca, G., Pandolfo, G., \& Zoccali, R. A. (2014). Role of negative affects in pathophysiology and clinical expression of irritable bowel syndrome. World journal of gastroenterology, 20(24), 7570-7586. https://doi.org/10.3748/wjg.v20.i24.7570.

13. Aladio, J. M., Costa, D., Matsudo, M., Pérez de la Hoz, A., González, D., Brignoli, A., Swieszkowski, S. P., \& Pérez de la Hoz, R. (2021). Cortisol-Mediated Stress Response and Mortality in Acute Coronary Syndrome. Current problems in cardiology, 46(3), 100623. https://doi.org/10.1016/j.cpcardiol.2020.100623. 